\title{
Developing Sustainable Livestock Production by Feed Adequacy Map: A Case Study in Pasuruan, Indonesia
}

\author{
R. Parmawati ${ }^{\mathrm{a}, *}$, Mashudi ${ }^{\mathrm{b}}$, A. Budiarto ${ }^{\mathrm{b}}$, Suyadi $^{\mathrm{b}}$, \& A. S. Kurnianto ${ }^{\mathrm{a}}$ \\ aPostgraduate, Brawijaya University \\ ${ }^{\mathrm{b}}$ Animal Husbandry Faculty, Brawijaya University \\ Jalan MT. Haryono 169, Malang, East Java, Indonesia \\ *Email of corresponding author: ritaparmawati1990@gmail.com \\ (Received 22-10-2017; Reviewed 12-12-2017; Accepted 11-01-2018)
}

\begin{abstract}
Feed is a main factor of sustainable livestock population, where the availability of suitable land for grass growth is urgent. Modern agriculture has dramatically reduced the diversity of forages due to the massive monoculture. This study was aimed to obtain data on the size of the existing land, distribution, potential feed production, and to obtain the carrying capacity based on feed adequacy map. The research was conducted on 6 dairy and beef cattle farms in Pasuruan Regency $\left(7^{\circ} 38^{\prime} \mathrm{S}, 112^{\circ} 54^{\prime} \mathrm{E}\right)$, East Java Province, Indonesia: Tutur, Puspo, Lumbang, Lekok, Grati, and Purwodadi. Population and distribution are represented spatially through thematic maps. The mapping using the Indonesia land-base map (Rира Bumi Indonesia-RBI) scale 1: 25,000, GPS handsets, and surveyors. Nguling had the highest beef cattle population (15,519 AU), while Tutur had the highest dairy cattle population $(22,033$ AU). Farmers were able to provide feed in the form of food-crop waste. Bangil had the highest carrying capacity of feed and safe criteria followed by Pohjentrek, while Lekok, Tutur, Puspo, Lumbang, Purwosari, Nguling, and Prigen subdistricts had very critical criteria. Based on the overall feed index, Pasuruan had a vulnerable criteria. The land carrying capacity status between land availability (SL) and land requirement (DL) was deficit. Less than $15 \%$ of land had low water carrying capacity. By carrying capacity index of crops waste (CCICW), the carrying capacity of food crops was high. The land carrying capacity status was deficit.
\end{abstract}

\section{Keywords: carrying capacity, map, livestock, Pasuruan}

\section{INTRODUCTION}

Feed provision is useful for increasing livestock populations, where the availability of grassland is an urgent issue. If the availability aspect of feed is not provided, the availability of livestock supply will be much reduced. Grass, in addition to animal feed, is also a potential land conservation tool. Land conservation encompasses many aspects, including the optimization of land use according to its designation without forgetting the maintenance of sustainable productivity (Lange et al., 2015). However, modern agriculture has dramatically reduced the diversity of forages species due to the massive application of monoculture systems. This fact is contrary to the concept of sustainable agriculture, which in addition to paying attention to the constantly increasing and changing needs of humans, we have to maintain or improve the quality of the environment and conserving natural resources (Hamuda \& Patko, 2010; Johannsen \& Armitage, 2010). Land, crops, and livestock are organic unities that are closely related and highly dependent on each other. These three components are triangular systems that must function synergistically to produce optimally, especially if the expected productivity goes on a sustainable basis (Soedjana, 2007; Hillmire,
2011; Gupta et al., 2012; Boitt et al., 2015; Ezeaku et al.; 2015).

Pasuruan is the main producer of meat and milk products in East Java, by its enormous amount of population (Disnak, 2016). With the Food Security Program, the Indonesian Government plans to make Pasuruan as a strategic livestock reserve region, by distributing calves to farmers. This plan is very risky, which it is not known the ability of land and other resources in receiving new populations and maintaining the existing population. Therefore, the carrying capacity of Pasuruan is needed to be studied before applying the government assistance. Based on the total of agriculture area $(80 \%$ of total area), we hypothesize that Pasuruan has sufficient carrying capacity for the program. This study aims to obtain data on the size of the existing land and its distribution, and to obtain the capacity of the land based on the potential feed production from the existing land.

\section{MATERIALS AND METHODS}

$$
\text { Mapping }
$$

The research was conducted on 6 dairy farms and beef cattle farms in 5 districts of Pasuruan Regency 
$\left(7^{\circ} 38^{\prime} \mathrm{S}, 112^{\circ} 54^{\prime} \mathrm{E}\right)$, East Java Province, Indonesia: Tutur, Puspo, Lumbang, Lekok, Grati, and Purwodadi. The study was conducted for 90 days (January-March, 2017). The data of population development and distribution of dairy and beef cattle were collected at the subdistrict level in a representative manner. Population development and recent distribution were represented spatially through thematic maps, which was obtained from survey and field interview. In addition, mapping was constructed using the land-base map of Rupa Bumi Indonesia (RBI) scale 1: 25,000, GPS handsets, and surveyors that gather information in the field for year 2017. Survey was conducted along with interview with topic: feed, feed source, and feeding volume for 1 month. Furthermore, the location coordinates were recorded. We categorize feed into 2 types: food-crop waste from agricultural and plantation waste, and natural feed from grass vegetation. Mapping the distribution of feed types, sources, and amount were done through direct surveys. All mapping procesess were analysed by QGIS ver. 2.1.4.

\section{Feeds Potency}

The uniformity of the cattle population was held following Ashari et al. (1997) with equalization in livestock (Animal Unit - AU), where cow was declared to have $A U=1$. The feed requirement for each animal unit (AU) was $9.1 \mathrm{~kg}$ dry matter/day. To find out the needs of the available feed, it can be calculated through the formula: Ruminants food requirement= Minimum feed requirements per $\mathrm{AU}(\mathrm{K})$ x Livestock population (AU) (Anggraini \& Putra, 2017).

As for the carrying capacity of the region, we used the formula as follows:

Region carrying capacity $=$ Total feed available / Feed requirement

A carrying capacity index was used to determine the ratio between total feed available and feed requirements:

Supporting power index $=($ Potential feed from waste + Natural feed potency) / Feed requirement

To estimate the capacity of a region, it can be calculated based on the formula (Ashari et al., 1999):

Area capacity $=($ Supporting power index / 4) $x$ Livestock population

If the area capacity was greater than the current livestock population, then the number of livestock could still be added. On the contrary, if the capability of the area was lower than the current livestock population, there is over capacity so that an alternative was needed for additional animal feed.

\section{SWOT Analysis}

This analysis aimed to determine the basic strategy for solving the current problem that could be applied qualitatively. SWOT was formed through the meeting of its components: 1) $\mathrm{SO}=$ strategy with maximum utilization of force $(S)$ to seize opportunity $(\mathrm{O})$; 2) ST= strategy with maximum utilization of force $(S)$ to anticipate threat $(\mathrm{T})$; 3) $\mathrm{WO}=$ strategy by minimizing weakness $(\mathrm{W})$ to seize opportunity $(\mathrm{O})$; 4) WT= strategy by minimizing weakness $(\mathrm{W})$ to avoid threat $(\mathrm{T})$. Components Strengths and Weaknesses were part of the Internal factor analysis, while Threats and Opportunities were part of the external factor analysis. Both were arranged to construct a SWOT matrix, i.e., through IFAS (Internal Factor Analysis System) and EFAS (External Factor Analysis System).

The IFAS and EFAS tables were organized by identifying 5-10 strengths and weaknesses, or opportunities and threats (column 1). Weights were given on each factor, ranging from 1.0 (very important) to 0.0 (not important) (column 2). The value of each factor was calculated by assigning a scale of 4 (outstanding) to 1 (poor) based on observation. Positive variables were positive, and vice versa. Weight and value were multiplied to get a score from 4.0 (outstanding) to 1.0 (poor). The score was added to get the total number of scores (column 4). The scores indicated that the environment will react to internal and external strategic factors. The total score of strength, weakness, opportunity, and threat factors were obtained from the results of internal and external data processing. The results of this calculation was used to determine the coordinate point for providing sufficient feed for livestock in Pasuruan Regency using grand strategy matrix analysis. In this case the horizontal axis $(X)$ were the internal factors and the vertical axis (Y) were external factors (Carpenter \& Sanders, 2007; Santosa et al., 2014).

\section{RESULTS}

Nguling Subdistrict had the highest beef cattle population (15,519 heads), while Tutur was the highest dairy cow population in Pasuruan Regency (22,033 heads). The population of beef cattle in Pasuruan in 2017 was 106,254 heads, which exceeded the achievement of population in 2016, which was 105,469 heads. This data showed an increase of $0.74 \%$ (Table 1 ).

The largest population of dairy cows was in Lekok and Tutur Subdistricts, followed by Puspo and Lumbang Subdistricts. The lowest population of dairy cattle was found in Rembang, Gempol, Kraton, and Wonorejo Subsdistrics. Tutur as a center of dairy cows is located in the mountains that have many sources of fresh natural feed, while other subdistricts with small population are industrial center and have a small or narrow agricultural area. Lekok has uniqueness, because of its location is in the lowlands (0-25 ASL- Above Sea Level). Survey results showed that farmers were able to provide feed in the form of food-crop waste (rice straw), as a form of adaptation to the lack of natural feed in the area. Some centers of beef cattle, such as Nguling, Purwosari, and Grati, also provided food-crop waste as a feed material. Some areas of beef cattle center in Prigen also provided natural feed, in addition to foodcrop waste.

Development of population of dairy cows and beef cattle in some subdistricts that had the highest population number was not possible to do, especially in Lekok and Tutur Subdistricts, whereas in Tosari and Prigen 
still had the potential to be developed considering the number of population and carrying capacity that were still possible and the population of dairy and beef cattle were still low (Figure 1).
Livestock raising should consider the balance of carrying capacity such as feed availability, abundance of food-crop waste, land suitability, and skilled human resources. Potential carrying capacity of food-crop waste

Table 1. The cattle and dairy cows in Pasuruan (2016)

\begin{tabular}{|c|c|c|c|c|c|c|}
\hline \multirow{2}{*}{ Subdistrict } & \multicolumn{2}{|c|}{ Beef cattle } & \multicolumn{2}{|c|}{ Dairy cows } & \multirow{2}{*}{ Total (AU) } & \multirow{2}{*}{$\%$} \\
\hline & Ind & $\mathrm{AU}$ & Ind. & $\mathrm{AU}$ & & \\
\hline Purwodadi & 7,710 & 5,397 & 6,754 & 4,728 & 10,125 & 7.49 \\
\hline Tutur & 1,168 & 817 & 22,033 & 15,423 & 16,240 & 12.01 \\
\hline Puspo & 32 & 23 & 11,292 & 7,904 & 7,927 & 5.86 \\
\hline Tosari & 82 & 57 & 3,219 & 2,253 & 2,310 & 1.71 \\
\hline Lumbang & 3,864 & 2,705 & 9,073 & 6,351 & 9,056 & 6.7 \\
\hline Pasrepan & 4,705 & 3,293 & 3,252 & 2,276 & 5,570 & 4.12 \\
\hline Kejayan & 8,031 & 5,622 & 55 & 39 & 5,660 & 4.19 \\
\hline Wonorejo & 5,899 & 4,129 & 9 & 6 & 4,136 & 3.06 \\
\hline Purwosari & 9,642 & 6,749 & 754 & 527 & 7,277 & 5.38 \\
\hline Prigen & 12,257 & 8,580 & 62 & 43 & 8,623 & 6.38 \\
\hline Sukorejo & 6,653 & 4,657 & 177 & 124 & 4,781 & 3.54 \\
\hline Pandaan & 2,235 & 1,564 & 4 & 3 & 1,567 & 1.16 \\
\hline Gempol & 5,427 & 3,799 & 8 & 6 & 3,804 & 2.81 \\
\hline Beji & 1,053 & 737 & 47 & 33 & 770 & 0.57 \\
\hline Bangil & 288 & 202 & 35 & 24 & 226 & 0.17 \\
\hline Rembang & 3,446 & 2,413 & - & - & 2,413 & 1.78 \\
\hline Kraton & 2,141 & 1,498 & 6 & 4 & 1,502 & 1.11 \\
\hline Pohjentrek & 203 & 142 & 22 & 16 & 158 & 0.12 \\
\hline Gondangwetan & 1,128 & 790 & 45 & 32 & 821 & 0.61 \\
\hline Rejoso & 396 & 277 & 505 & 354 & 631 & 0.47 \\
\hline Winongan & 2,856 & 1,999 & 171 & 120 & 2,119 & 1.57 \\
\hline Grati & 8,797 & 6,158 & 5,059 & 3,542 & 9,699 & 7.18 \\
\hline Lekok & 2,722 & 1,905 & 22,703 & 15,892 & 17,797 & 13.17 \\
\hline Nguling & 15,519 & 10,863 & 1,562 & 1,093 & 11,956 & 8.85 \\
\hline
\end{tabular}

Note: $\mathrm{AU}=$ Animal unit.

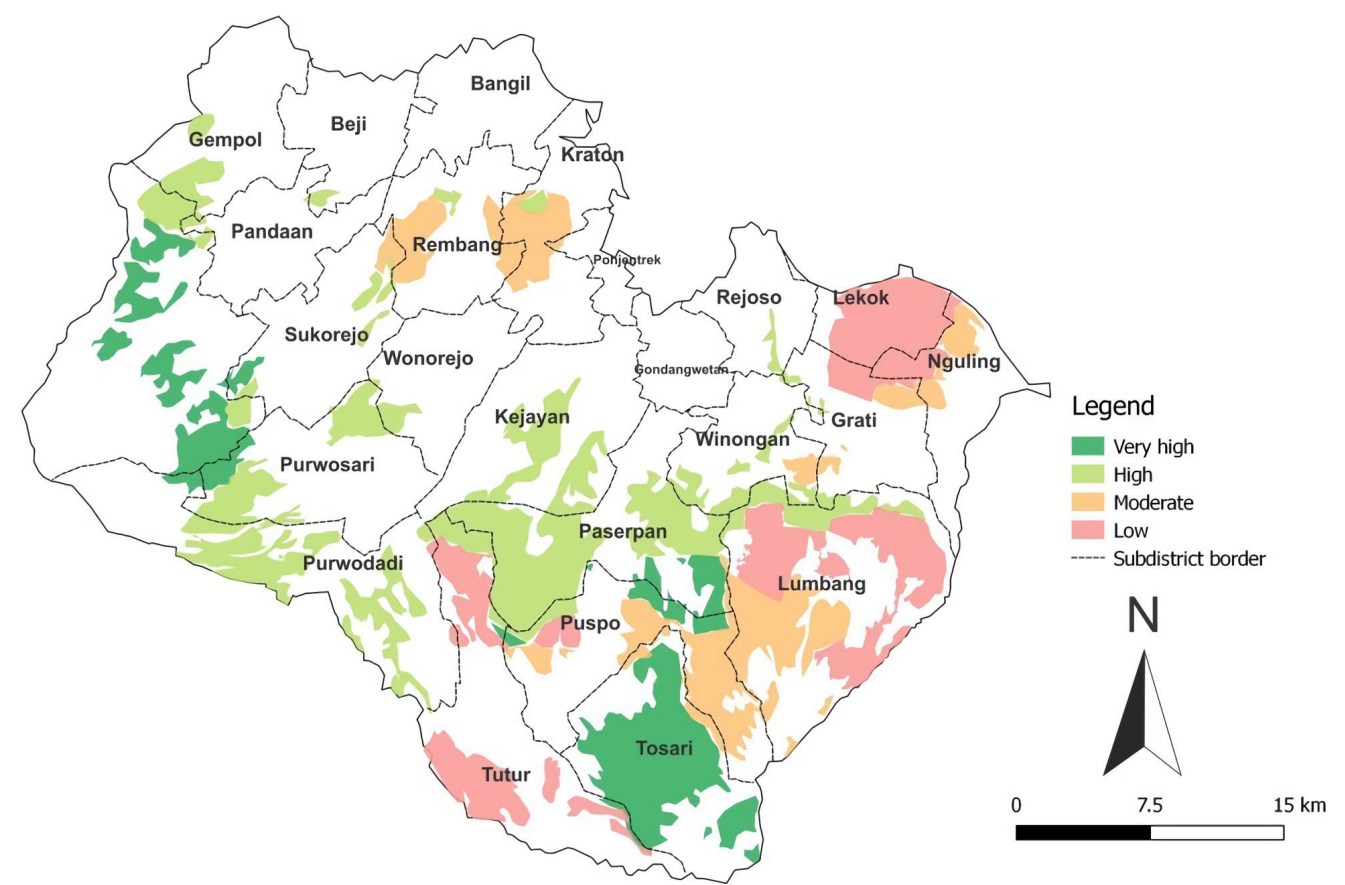

Figure 1. Potential of livestock development in Pasuruan 
in all subdistricts were dominated by corn, rice, and sugar cane (Table 2).

Kejayan was the largest food-crop waste producer, while the lowest was Lengkok. The largest source of food-crop waste came from rice crops. The amount of digestible dry matter, dry matter digestibility (DMD), as a derivative product of food-crop waste was vary in each subdistrict. The highest number of DMD potentials was found in Kejayan and the lowest was in Tosari (Table 3).

The carrying capacity index of crops waste (CCICW) (Ismael et al., 2018) between the carrying capacity of food crops waste and the number of ruminant livestock population in each subdistrict was grouped based on four index categories: low, medium, safe, and high categories (Table 4). By the total, the carrying capacity of food crops in Pasuruan was in high status. Based on this results, it could be mapped as showed in Figure 2.

The total number of livestock in Pasuruan Regency was 245,658.42 (livestock land adequacy unit), meaning that the population required a land of $245,658.42$ multiplied by $3 \mathrm{~m}^{2}$ (minimum requirement of space per Unit of livestock or cattle, based on the regulation of Minister of Agriculture No 54/2006 the total is 73,72 Ha. The overall land requirement for livestock in Pasuruan Regency was 426,607.72 Ha, while the area of Pasuruan according to data of BPS (2014) was 147,402 Ha (1,474.02 $\mathrm{km}^{2}$ ). This fact showed the land carrying capacity status between land availability (SL) and land requirement (DL) was otherwise lack.

Table 2. Production of rice straw, maize, and sugar cane in Pasuruan, 2013 (Ton)

\begin{tabular}{|c|c|c|c|c|}
\hline Subdistrict & Rice straw & Maize & Sugar cane & Total \\
\hline Purwodadi & 31628 & 6834 & 1708.5 & 40,171 \\
\hline Tutur & 0 & 19168 & 4792 & 23,960 \\
\hline Puspo & 0 & 19923 & 4980.75 & 24,904 \\
\hline Tosari & 0 & 15840 & 3960 & 19,800 \\
\hline Lumbang & 1291 & 11595 & 2898.75 & 15,785 \\
\hline Pasrepan & 7533 & 17614 & 4403.5 & 29,551 \\
\hline Kejayan & 59829 & 18413 & 4603.25 & 82,845 \\
\hline Wonorejo & 28796 & 13840 & 3460 & 46,096 \\
\hline Purwosari & 46229 & 9644 & 2411 & 58,284 \\
\hline Prigen & 26349 & 5755 & 1438.75 & 33,543 \\
\hline Sukorejo & 42279 & 10502 & 2625.5 & 55,407 \\
\hline Pandaan & 43959 & 612 & 153 & 44,724 \\
\hline Gempol & 28615 & 1817 & 454.25 & 30,886 \\
\hline Beji & 41457 & 65 & 16.25 & 41,538 \\
\hline Bangil & 18111 & 303 & 75.75 & 18,490 \\
\hline Rembang & 36582 & 4447 & 1111.75 & 42,141 \\
\hline Kraton & 38601 & 6110 & 1527.5 & 46,239 \\
\hline Pohjentrek & 9143 & 1122 & 280.5 & 10,546 \\
\hline Gondangwetan & 37161 & 3823 & 955.75 & 41,940 \\
\hline Rejoso & 32917 & 0 & 0 & 32,917 \\
\hline Winongan & 27275 & 5897 & 1474.25 & 34,646 \\
\hline Grati & 17336 & 17135 & 4283.75 & 38,755 \\
\hline Lekok & 8730 & 1148 & 287 & 10,165 \\
\hline Nguling & 11319 & 22663 & 5665.75 & 39,648 \\
\hline Total & 595,140 & 214,270 & $53,567.50$ & $862,977.50$ \\
\hline
\end{tabular}

Secondary component that can support the compatibility of land for livestock is water, which consists of slopes of land, water availability index, aquifer depth, and affix areas. The slopes of land that can be utilized for livestock are in the category of strata two, ie, slopes of less than or equal to $15 \%$ (slopes $\leq 15 \%$ ), and part of the land having slopes of less than or equal to $35 \%$ (slope $\leq 35 \%$ ) can be utilized by modifying the contour of the land with terraces. The processing of land use in Pasuruan was still less than optimal, while groundwater exploration in various sectors continued to increase. The calculation of land capability unit (LCU) of groundwater availability was determined by the type of constituent rock, rainfall, surface soil type, land slope, and groundwater depth (Grose, 1999). The types of constituent rocks were classified based on permeability values that were influenced by the texture and structure of each rock type.

The existing condition of Pasuruan highlands had moderate, high, and very high rainfall, while some areas in lowland had low rainfall. The type of soil covering most of the three categories of clay and sand had medium to fast permeability. Mapping of groundwater availability based on the overlay of the five secondary supporting data, weight of score, and the value of each parameter make LCU of ground water was large (831.6 Ha with $10 \mathrm{~L} / \mathrm{sec}-200 \mathrm{~L} / \mathrm{sec}$ ). Based on the analysis result, which included rock gradation classification map, rainfall classification map, land cover classification map, land slope map, and groundwater depth classification map, less than $15 \%$ of land had low water carrying capacity (Figure 3).

Table 3. Number of dry matter digestibility of food-crop waste in Pasuruan (Ton)

\begin{tabular}{|c|c|c|c|c|}
\hline Subdistrict & Rice straw & Maize & Sugar cane & Total \\
\hline Purwodadi & 29066.1 & 1435.1 & 666.3 & 31167.6 \\
\hline Tutur & 0.0 & 4025.3 & 1868.9 & 5894.2 \\
\hline Puspo & 0.0 & 4183.8 & 1942.5 & 6126.3 \\
\hline Tosari & 0.0 & 3326.4 & 1544.4 & 4870.8 \\
\hline Lumbang & 1186.4 & 2435.0 & 1130.5 & 4751.9 \\
\hline Pasrepan & 6922.8 & 3698.9 & 1717.4 & 12339.1 \\
\hline Kejayan & 54982.9 & 3866.7 & 1795.3 & 60644.8 \\
\hline Wonorejo & 26463.5 & 2906.4 & 1349.4 & 30719.3 \\
\hline Purwosari & 42484.5 & 2025.2 & 940.3 & 45450.0 \\
\hline Prigen & 24214.7 & 1208.6 & 561.1 & 25984.4 \\
\hline Sukorejo & 38854.4 & 2205.4 & 1023.9 & 42083.8 \\
\hline Pandaan & 40398.3 & 128.5 & 59.7 & 40586.5 \\
\hline Gempol & 26297.2 & 381.6 & 177.2 & 26855.9 \\
\hline Beji & 38099.0 & 13.7 & 6.3 & 38119.0 \\
\hline Bangil & 16644.0 & 63.6 & 29.5 & 16737.2 \\
\hline Rembang & 33618.9 & 933.9 & 433.6 & 34986.3 \\
\hline Kraton & 35474.3 & 1283.1 & 595.7 & 37353.1 \\
\hline Pohjentrek & 8402.4 & 235.6 & 109.4 & 8747.4 \\
\hline Gondangwetan & 34151.0 & 802.8 & 372.7 & 35326.5 \\
\hline Rejoso & 30250.7 & 0.0 & 0.0 & 30250.7 \\
\hline Winongan & 25065.7 & 1238.4 & 575.0 & 26879.1 \\
\hline Grati & 15931.8 & 3598.4 & 1670.7 & 21200.8 \\
\hline Lekok & 8022.9 & 241.1 & 111.9 & 8375.9 \\
\hline Nguling & 10402.2 & 4759.2 & 2209.6 & 17371.0 \\
\hline Total & 546933.7 & 44996.7 & 20891.3 & 612821.7 \\
\hline
\end{tabular}


Table 4. Carrying capacity index of crops waste (CCICW) in Pasuruan

\begin{tabular}{|c|c|c|c|c|}
\hline Subdistrict & $\begin{array}{c}\text { DMD } \\
\text { potency }\end{array}$ & $\begin{array}{c}\text { Total need } \\
\text { of DMD } \\
(1.14 \text { ton } \\
\text { DMD /AU) }\end{array}$ & CCICW & $\begin{array}{c}\text { Regional } \\
\text { Status based } \\
\text { on CCICW }\end{array}$ \\
\hline Purwodadi & 31167.59 & 11390.88 & 2.74 & High \\
\hline Tutur & 5894.16 & 17139.9 & 0.34 & Low \\
\hline Puspo & 6126.323 & 8417.76 & 0.73 & Low \\
\hline Tosari & 4870.8 & 3505.5 & 1.39 & Safe \\
\hline Lumbang & 4751.892 & 10461.78 & 0.45 & Low \\
\hline Pasrepan & 12339.13 & 6390.84 & 1.93 & Moderate \\
\hline Kejayan & 60644.85 & 6422.76 & 9.44 & High \\
\hline Wonorejo & 30719.32 & 4899.72 & 6.27 & High \\
\hline Purwosari & 45449.98 & 7680.18 & 5.92 & High \\
\hline Prigen & 25984.39 & 9823.38 & 2.65 & High \\
\hline Sukorejo & 42083.77 & 5323.8 & 7.9 & High \\
\hline Pandaan & 40586.51 & 1976.76 & 20.53 & High \\
\hline Gempol & 26855.91 & 4531.5 & 5.93 & High \\
\hline Beji & 38118.97 & 1352.04 & 28.19 & High \\
\hline Bangil & 16737.18 & 469.68 & 35.64 & High \\
\hline Rembang & 34986.31 & 3014.16 & 11.61 & High \\
\hline Kraton & 37353.14 & 2078.22 & 17.97 & High \\
\hline Pohjentrek & 8747.432 & 231.42 & 37.8 & High \\
\hline Gondangwetan & 35326.53 & 1326.96 & 26.62 & High \\
\hline Rejoso & 30250.72 & 953.04 & 31.74 & High \\
\hline Winongan & 26879.05 & 2502.3 & 10.74 & High \\
\hline Grati & 21200.8 & 10836.84 & 1.96 & Moderate \\
\hline Lekok & 8375.88 & 19166.82 & 0.44 & Low \\
\hline Nguling & 17371.03 & 13503.3 & 1.29 & Safe \\
\hline Total & 612821.7 & 153399.5 & 3.99 & High \\
\hline
\end{tabular}

Note: $\mathrm{DMD}=$ dry matter digestibility; $\mathrm{AU}=$ Animal unit.

The water recharge area in Pasuruan is located in Arjuna Mountain area consisting of Prigen, Purwosari, and Purwodadi covering $135.57 \mathrm{~km}^{2}$ and recharge area in Bromo Mountain area covering Tutur, Tosari, Puspo, and Lumbang with total area of $312 \mathrm{~km}^{2}$. Land availability unit of ground water availability in Pasuruan was high with $831.6 \mathrm{Ha}$ with a great potency of ground water according to Dinas ESDM of 43 million $\mathrm{m}^{3} /$ year. Then, we could conclude it on map of vegetation distribution (Figure 4). In addition, the grass area that could be used as forages was spread widely. It was also supported by agricultural areas that could produce food-crop waste as feed. These facts are a positive influence in understanding the sustainability of livestock in Pasuruan, where the results of the previous analysis showed the land lack for livestock needs.

\section{Map of Adequacy and Strategies}

The highest total feed production was found in Kejayan Subdistrict, followed by Grati, Purwosari, Sukorejo, Beji, Kraton, and Winongan, while the lowest was Tutur, followed by Tosari, Pohjentrek, and Puspo Subdistricts. Tutur and Puspo Subdistricts were densely populated areas but the availability of feed was quite low, while Sukorejo, Beji, Kraton, and Winongan Subdistricts had plenty of feed but the livestock population was quite low. Based on the analysis, the district that had the highest positive development potency was Kejayan Subdistrict followed by Beji, Rejoso, Winongan, and Pandaan Subsdistricts.

The highest carrying capacity of feed and safe criteria were found in Bangil Subdistrict followed by Pohjentrek, Rejoso, and Beji Subsdistricts, while the lowest value was found in Lekok, Tutur, Puspo, Lumbang, Purwosari, Nguling, and Prigen Subdistricts and had very critical criteria indexes. Based on the overall feed index, Pasuruan had a vulnerable criteria (Figure 5).

The strategy of providing sufficient feed for livestock in Pasuruan was held by SWOT (Figure 6) with EFAS (External Factor Analysis Strategy)-IFAS (Internal Factor Analysis Strategy). The variables in this SWOT analysis were strengths, weaknesses, opportunities, and threats. The total strength score of IFAS was 1.95, which was greater than the total score of the weakness variable (1.15). The EFAS value of the opportunity variable (2.04) was greater than the threat variables (1.43) Both IFAS and EFAS score showed that the provision of feed in Pasuruan was enough to meet the needs of livestock.

The total score of the internal factors (3.10) was smaller than the external factor (3.47). This result indicated that external factors were more influential than internal factors in providing sufficient feed for livestock in Pasuruan Regency.Therefore, to provide adequate feed for livestock in Pasuruan District we can optimize the external factors, namely seize the opportunity and find solutions from the threat faced by Kabupaten Pasuruan, as well as adding internal factors, that is, utilizing the strength and minimizing the weakness. In this equation case, as the horizontal axis $(\mathrm{X})$ was internal factor with a value of $X=(1.95-1.15)=0.80$ and the vertical axis $(Y)$ was external factor with a value of $Y=(2.04-1.43)=0.61$.

The grand strategy matrix showed that the position of Pasuruan in feed development position was in the position of quadrant 1 (Figure 7). This fact is a situation that Pasuruan has a great opportunity to develop in accordance with its strength, so the strategy used is to minimize internal problems that exist to produce some great opportunities. The form of strategy to be chosen should be in accordance with stable growth.

\section{DISCUSSION}

Some reasons for the increased beef cattle population in Pasuruan are the increased performance of artificial insemination, control of inter-regional livestock expenditure, and prohibition of productive female slaughtering in accordance with the Act no. 41/2014 on prohibition of productive female slaughtering (Kemenkopmk, 2014). Dry matter digestibility has become the main source of feed in various regions that have small natural feed production capability. The fruits and vegetables waste have important ingredients for livestock, such as phytochemicals (carotenids, phenolics, and flavonoids), antioxidants, antimicrobials, vitamins, or fats, which are enriched by an advance technological systems (Schieber, 2001; Fernández-López, 2008; Rahman et al., 2014; Saleemdeeb, 2017). Feed from organic waste materials has been traditionally used, and new technology can be used to convert it into a qual- 


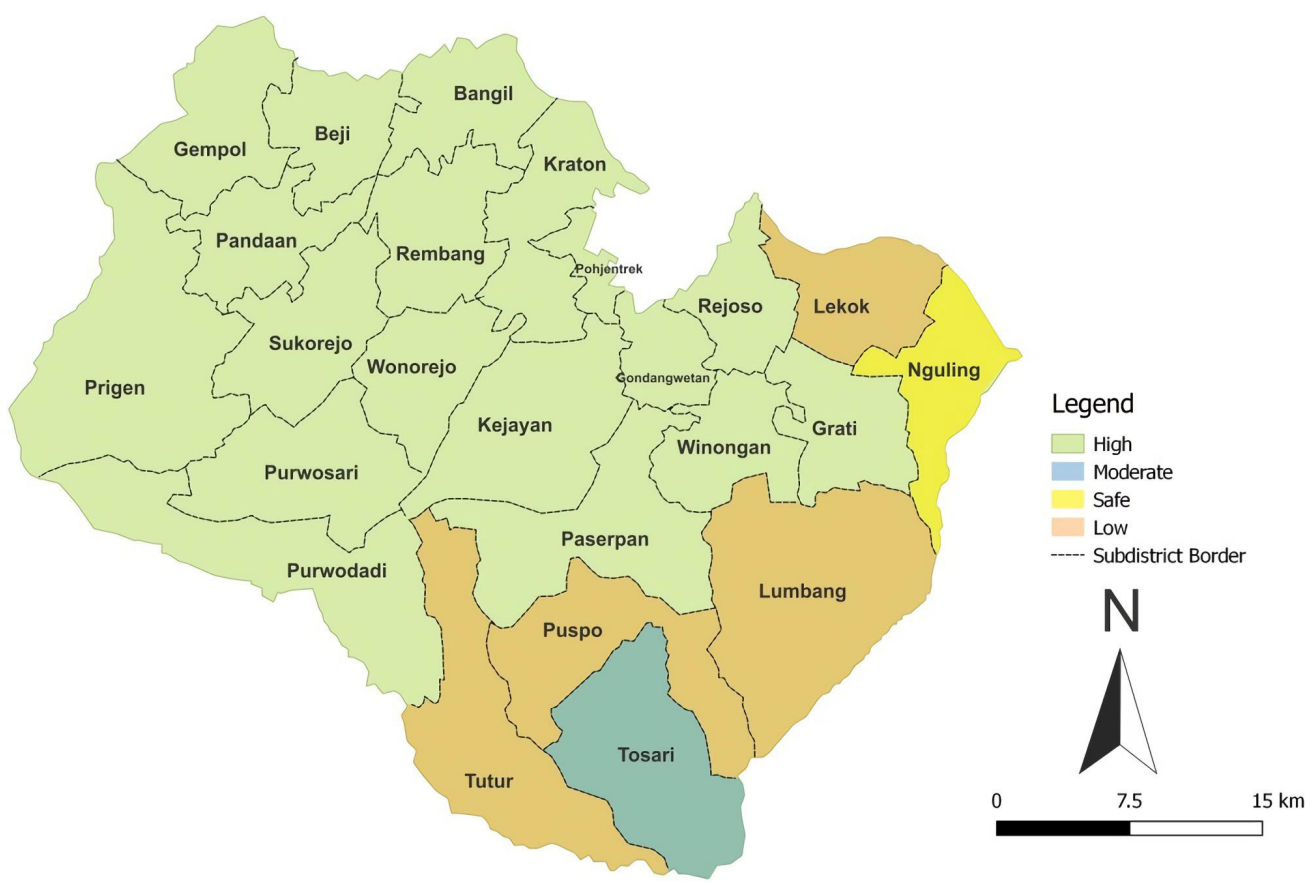

Figure 2. Food crop waste support factor in Pasuruan

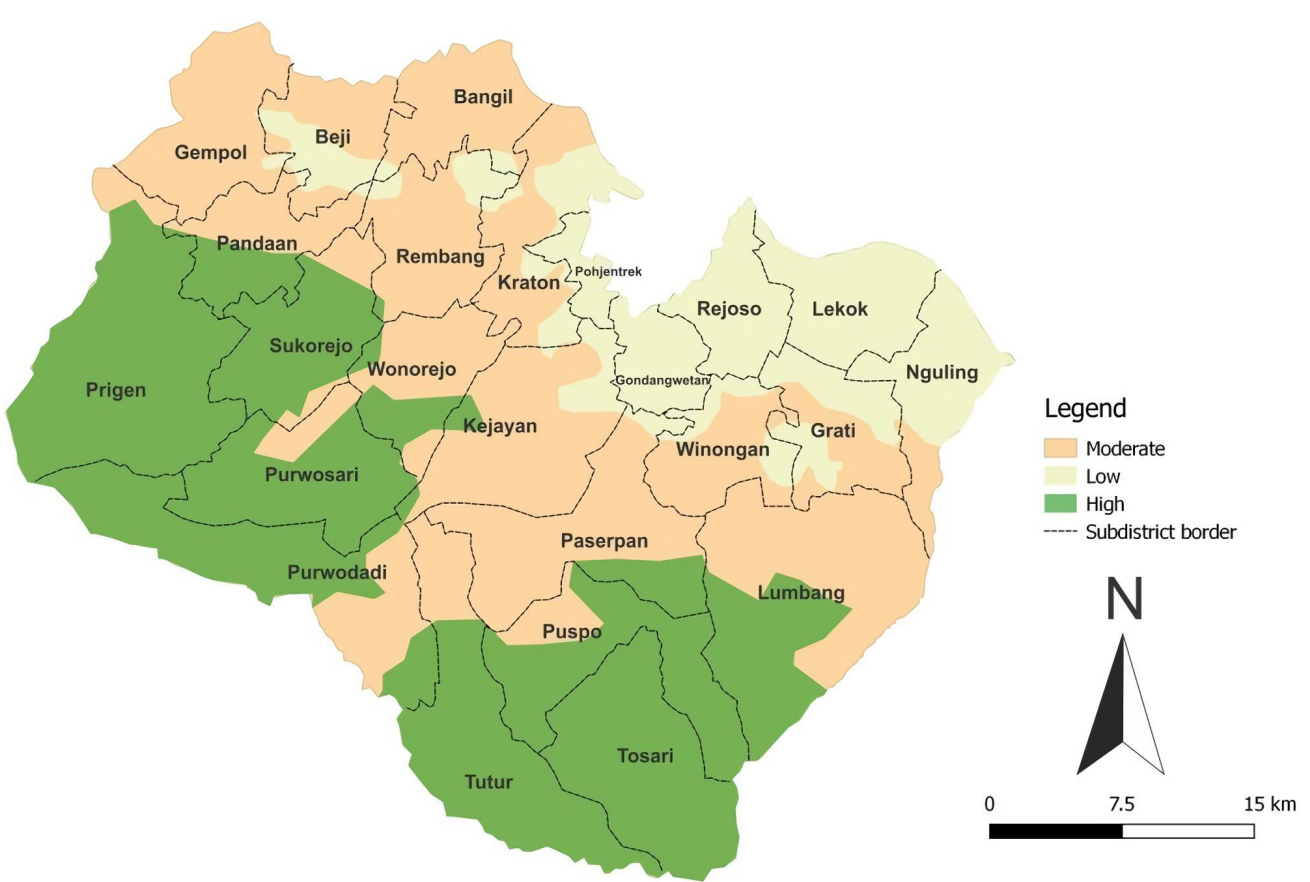

Figure 3. Map of water supporting capacity in Pasuruan Regency

ity livestock feed at a relatively affordable production (Sorathiya et al., 2014; Kasapidou, 2015). Food production is unable to compete with the need of feed, energy, and other production commodities. This lag can be avoided by zero-waste farming practices. The dry matter digestibility of Pasuruan has lignocellulosic and nonlignocellulosic materials, in which the composition is present in harvested plant species. This fact shows that all of these materials can be used as energy, food, feed, fertilizer, fuel, and other product formations (Doelle et al., 2009; Calt, 2015; Surendra et al., 2016). This means that the support of food crop waste is very important for the sustainability of livestock in Pasuruan.

This study shows that the high demand for feed and land requirement components will soon be occurred in Pasuruan, due to the large number of areas that have degraded into non-agricultural areas. This deficit will be transformed into a livestock degradation, if not through 


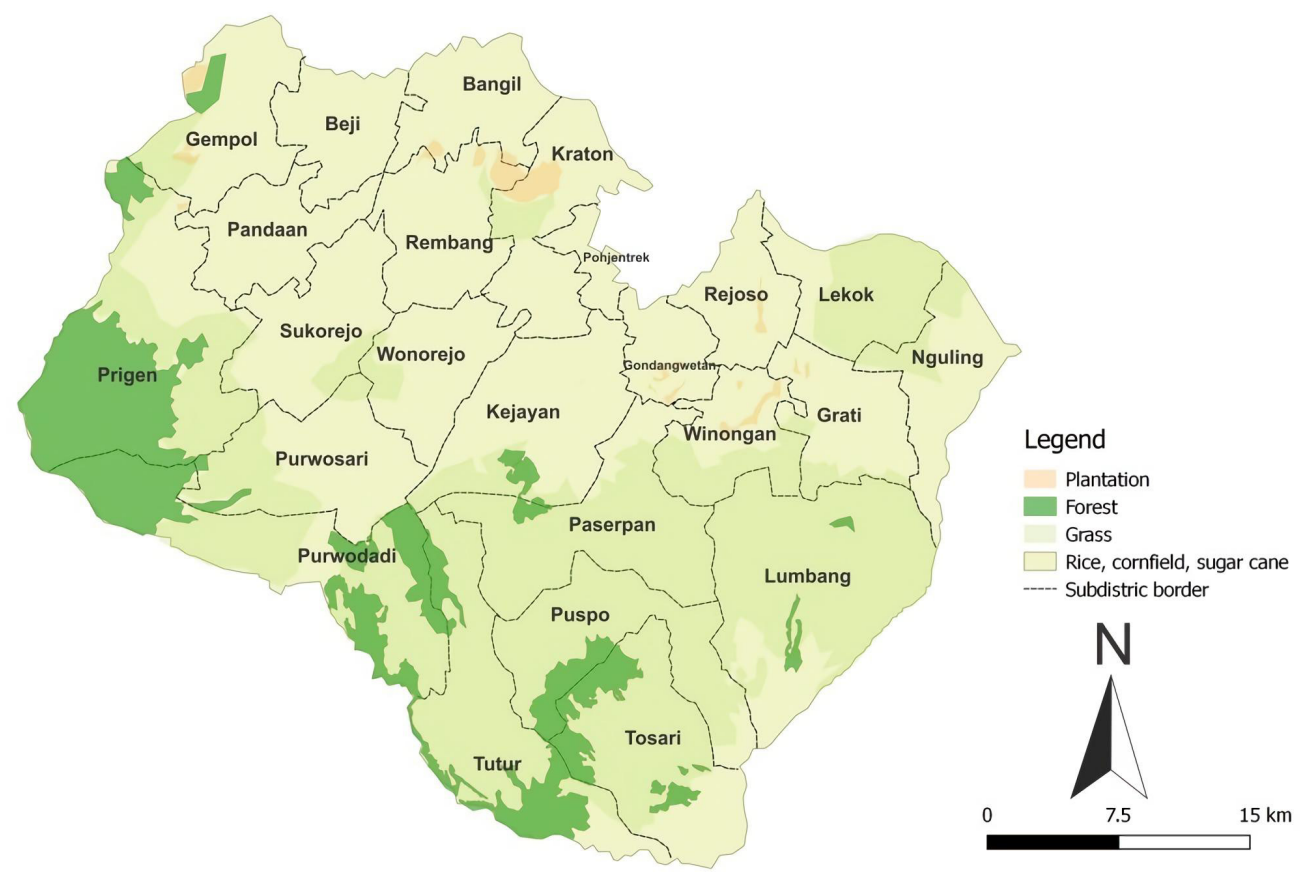

Figure 4. Vegetation and water recharge area distribution in Pasuruan

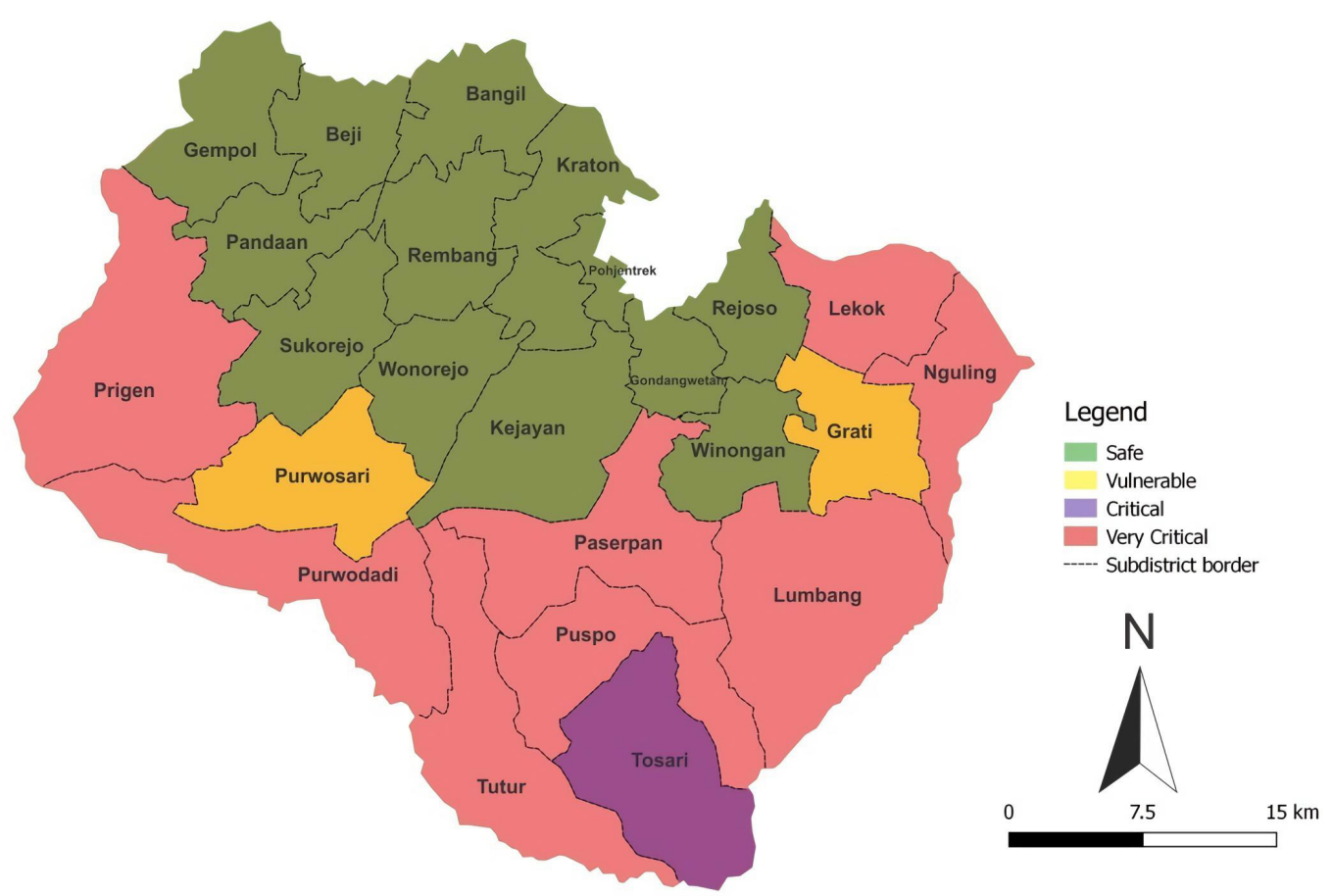

Figure 5. Map of adequacy from carrying capacity index of crops waste

a modern intensification (Thornton, 2010). There is a relationship between livestock and agricultural production, which supports the growth of densely populated livestock, or allows it to be intensively developed in agricultural areas (Bos et al., 2013; Pretty \& Bharucha, 2014; Rahman, 2015). In contrast, degradation of agricultural areas will significantly reduce livestock populations and sustainability (Deshar, 2013; Tesfa \& Mekuriaw, 2014;
Sonneveld et al., 2016). A fundamental question is how Pasuruan livestock industries can survive in the future, which is also supported by other farm components, such as vegetation and water.

Water is one of the main livestock supporting components. In addition to the needs for consumption, water is the possibility of natural feed development which derived from agricultural areas. Water is also used as a 


\begin{tabular}{|c|c|c|}
\hline EFAS & $\begin{array}{l}\text { STRENGTH (S) } \\
\text { 1. Feed resources from food crop waste } \\
\text { has a large enough production } \\
\text { 2. Production of food crop waste spread in } \\
\text { all areas of Pasuruan Regency } \\
\text { 3. Food crop waste is not used other than } \\
\text { for animal feed } \\
\text { 4. Development of livestock feed is still } \\
\text { possible in Pasuruan Regency } \\
\text { 5. Dairy milk production in Pasuruan } \\
\text { Regency occupies the highest rate in } \\
\text { East Java ( } 25 \%) \text {. }\end{array}$ & $\begin{array}{l}\text { WEAKNESSES (W) } \\
\text { 1. The nutritional quality of food crop } \\
\text { waste is low } \\
\text { 2. The business of ruminant livestock is } \\
\text { still sideline } \\
\text { 3. The pattern of livestock raising is still } \\
\text { relatively traditional } \\
\text { 4. The application level of food processing } \\
\text { technology for food crop waste is still } \\
\text { low } \\
\text { 5. The production of food crop waste is } \\
\text { still seasonal }\end{array}$ \\
\hline $\begin{array}{l}\text { OPPORTUNITY (O) } \\
\text { 1. The population of ruminant } \\
\text { livestock is quite high } \\
\text { 2. Support policy of Pasuruan } \\
\text { Regency's livestock } \\
\text { development } \\
\text { 3. Generally farmers maintain } \\
\text { their own livestock and } \\
\text { food crop agriculture } \\
\text { 4. The use of crop waste for } \\
\text { ruminant livestock has not } \\
\text { been optimal } \\
\text { 5. The price of local beef is } \\
\text { higher than imported meat } \\
\text { 6. Reduce unemployment rate } \\
\text { in Pasuruan Regency }\end{array}$ & $\begin{array}{l}\text { 1. Increasing the utilization of feed from } \\
\text { industrial waste of plantation and food } \\
\text { crops (S1, S2, S3, S4, O1,O3, O4) } \\
\text { 2. To formulate a policy of prohibition } \\
\text { and/or restrict imports or outsourcing } \\
\text { of regions, related to the procurement of } \\
\text { livestock commodities and derivative } \\
\text { products (S5, O1, O2, O5, O6) } \\
\text { 3evelopment of livestock green feed } \\
\text { area with respect to Detailed and } \\
\text { District Spatial Planning (S1, S2, S4, O2, } \\
\text { O4) } \\
\text { 4. Increasing the human resources of } \\
\text { farmers in order to manage good and } \\
\text { hygienic cultivation of good (S1, S3, S4, } \\
\text { O2, O3, O4) } \\
\text { Research and development of feed } \\
\text { utilization from food crop waste (S1, S2, } \\
\text { S3, S4, O2, O3, O4) } \\
\text { Increasing the production of cow's milk } \\
\text { in East Java will increase the number of } \\
\text { dairy farmers and reduce } \\
\text { unemployment (S1, S2, S4, S5, O1, O5, } \\
\text { O6) }\end{array}$ & $\begin{array}{l}\text { 1. Research and development of feed } \\
\text { utilization from food crop waste (W1, } \\
\mathrm{W} 2, \mathrm{~W} 3, \mathrm{~W} 4, \mathrm{~W} 5, \mathrm{O} 2, \mathrm{O} 4) \\
\text { 2. Increasing public awareness to pursue } \\
\text { cattle business professionally (W2, W3, } \\
\mathrm{W} 5, \mathrm{O} 2, \mathrm{O} 3, \mathrm{O} 4) \\
\text { 3. Establish a buffer institution in the form } \\
\text { of Business and Marketing Incubator } \\
\text { Institution to oversee, foster, support } \\
\text { system for all livestock commodities in } \\
\text { Pasuruan (W2, W3, O1, O2) } \\
\text { 4. Increasing the utilization of feed from } \\
\text { industrial waste of plantation and food } \\
\text { crops (W5, O1, O4, O5) } \\
\text { 5. The existence of government programs } \\
\text { to provide cattle to the community to } \\
\text { increase the number of dairy cows and } \\
\text { reduce unemployment (W2, W3, O2, O5, } \\
\text { O6) }\end{array}$ \\
\hline $\begin{array}{l}\text { THREATS (T) } \\
\text { 1. The habits of farmers who } \\
\text { always burn the crops of } \\
\text { food crops } \\
\text { 2. Imports of livestock and } \\
\text { meat are increasing for } \\
\text { consumers' needs } \\
\text { 3. The unstable supply and } \\
\text { quality of feed } \\
\text { 4. The unstable price of cow's } \\
\text { milk from breeders }\end{array}$ & $\begin{array}{l}\text { 1. Training to the community about the } \\
\text { utilization of food crop waste (S1, S2, } \\
\text { S3, S4, T1) } \\
\text { 2. To formulate a policy of prohibition and } \\
\text { or to restrict imports or outsourcing of } \\
\text { regions, related to the procurement of } \\
\text { livestock commodities and derivative } \\
\text { products (S5, T2, T4) } \\
\text { 3. Applying natural feed area in Pasuruan } \\
\text { Regency and modernly cultivated (S1, } \\
\text { S2, S3, S4, T1, T3) } \\
\text { 4. The existence of SOP from Pemkab } \\
\text { Pasuruan to determine the lowest price } \\
\text { and the highest price of cow's milk in } \\
\text { breeders (S5, T4) }\end{array}$ & $\begin{array}{l}\text { 1. Build a livestock health home equipped } \\
\text { with supporting facilities (W3, T1, T3) } \\
\text { 2. To formulate a policy of prohibition and } \\
\text { or to restrict imports or outsourcing of } \\
\text { regions, related to the procurement of } \\
\text { livestock commodities and derivative } \\
\text { products (W2, W3, , T2, T4) } \\
\text { 3. Increasing public awareness to pursue } \\
\text { cattle business professionally (W2, W3, } \\
\text { T2, T4) } \\
\text { 4. Establish a buffer institution in the form } \\
\text { of Business Incubator and Marketing } \\
\text { Institution to oversee, foster, support } \\
\text { system for all livestock commodities in } \\
\text { Pasuruan (W2, W3, T2, T4) } \\
\text { 5. Applying natural feed area in Pasuruan } \\
\text { Regency and modernly cultivated (W1, } \\
\text { W4, W5, T1, T3) }\end{array}$ \\
\hline
\end{tabular}

Figure 5. SWOT Analysis

basic requirement of livestock production (Ahaneku, 2010; Hoekstra, 2012). The use of water in livestock production shall be in accordance with an integral part of the management of water resources derived from different production systems (Blummel et al., 2010). Livestock water requirements may also compete with human populations and agricultural production needs (Mijinyawa \& Dlamini, 2008). Agriculture can use rainwater directly or through irrigation, while animals consume plants or grass, which will lead to a reduction of water efficiency in food production (Schlink et al., 2010; Scholtz et al., 2013; Yosef \& Asmamaw, 2015).

Strategies to increase the population of cattle in Pasuruan are a priority in order to become a center of cattle production and to support the national food security program. These programs are aimed to increase 


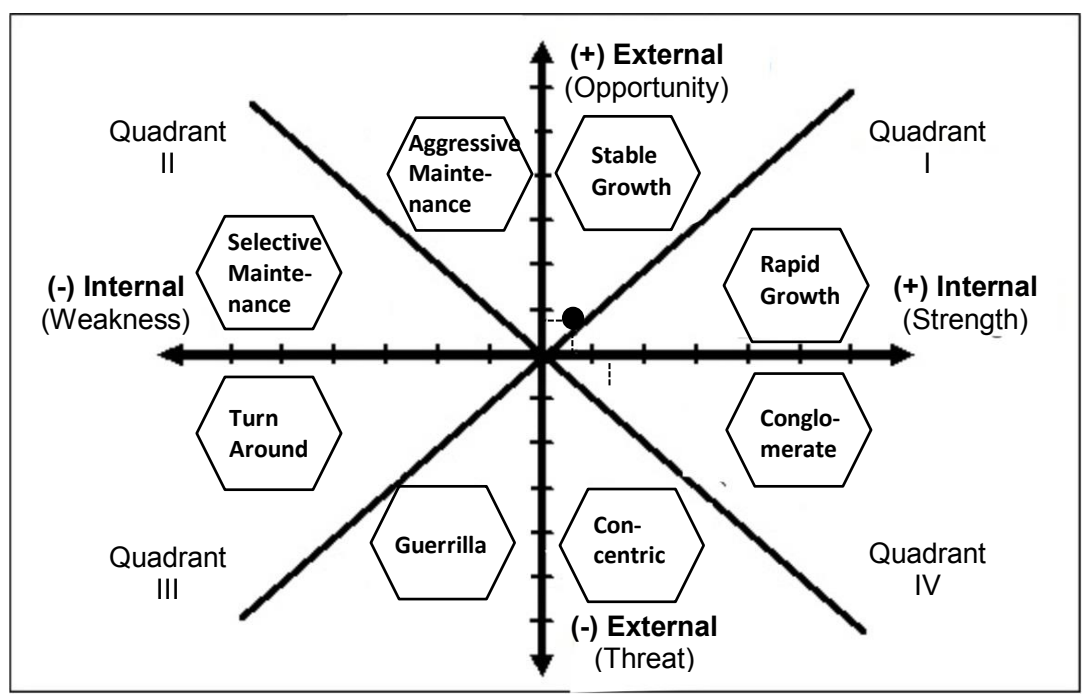

Figure 7. Grand strategy matrix

the utilization of food from plantation and food crops. In addition the program is also aimed to formulate policies to restrict imports or outsourcing of regions, related to the procurement of livestock commodities and its derivative products. The other aims of the program were the development of livestock green feed areas with respect to detailed spatial planning and district spatial planning (Schroll et al., 2012) and the improvement of farmers human resources in order to manage good and hygienic cultivation, research, as well as the development of feed utilization based on food crop waste, and enhancing meat and milk production in East Java. These strategies will increase the number of cattle farmers and reduce unemployment. Further research is needed on the growth of dairy and cattle beef naturally, improvement in various fields, and formulating supervisory policies related to livestock procurement.

\section{CONCLUSION}

The land carrying capacity status between land availability (SL) and land requirement (DL) is deficit. Less than $15 \%$ of land has low water carrying capacity. However, based on carrying capacity index of crops waste, there are 16 subdistricts that can support livestock development with high status, 2 with safe status, 1 with moderate status, and 4 with low status. The highest total feed production is in Kejayan Subdistrict, followed by Grati, Purwosari, Sukorejo, Beji, Kraton, and Winongan Subdistricts, while the lowest is in Tutur, followed by Tosari, Pohjentrek, and Puspo Subdistricts. The highest carrying capacity of feed and safe criteria exist in Bangil Subdistrict followed by Pohjentrek, Rejoso, and Beji Subsdistricts, while the lowest value is in Lekok, Tutur, Puspo, Lumbang, Purwosari, Nguling, and Prigen Subsdistricts. Based on the overall feed index, Pasuruan is cathegorised as a vulnerable criteria.

\section{REFERENCES}

Ahaneku, I.E. 2010. Conservation of soil and water resources for combating food crisis in Nigeria. Scientific Research and Essays.5.6:507-513

Anggraini, N. \& R.A. Putra. 2017. Analisis potensi wilayah dalam pengembangan peternakan sapi potong di Kecamatan Sijunjung Kabupaten Sijunjung. Jurnal AGRIFO. 2:82-100.

Ashari, E., E. Juarini, Sumanto, Wibowo, \& Suratman. 1997. Pedoman Analisis Potensi Wilayah Penyebaran dan Pengembangan Peternakan. BPT dan Direktorat Bina Penyebaran dan Pengembangan Peternakan, Jakarta.

Blummel, M., A. Haileslassie, F. Clement, S. Ishaq, \& M.A. Khan. 2010. Adapting livestock water productivity to climate change. International Journal of Climate Change Strategies and Management. 3.2:156-169.

Boitt, M.K., C.N. Mundia, P.K.E. Pellikka, \& J.K. Kapoi. 2015. Land suitability assessment for effective crop production, a case study of Taita Hills, Kenya. Journal of Agricultural Informatics. 6.2:23-31. https://doi.org/10.17700/ jai.2015.6.2.185

Bos, J.F.F.P, A.B.L Smit, \& J.J. Schroder. 2013. Is agricultural intensification in the Netherlands running up to its limits? Wageningen Journal of Life Sciences. 55:65-73. https://doi. org/10.1016/j.njas.2013.06.001

Calt, E.A. 2015. Products produced from organic waste using managed Ecosystem Fermentation. J. Sustain. Dev. 8.3.43-51

Carpenter, M.A \& Sanders, W.G. 2007. Strategic Manajemen: Concepts and Cases. Pearson Australia, Australia.

Deshar, B.D. 2013. An overview of agricultural degradation in Nepal and its impact on economy and environment. Global Journal of Economic and Social Development. 3.1:1-20

Disnak. 2016. Data statistik populasi ternak, Provinsi Jawa Timur. http://www.disnak.jatimprov.go.id/web/data/ datastatistik. [1 November 2017].

Doelle, H.W., S. Rokem, and M. Berovic. 2009. Biotechnology: Fundamentals in Biotechnology. EOLSS Publishers/ UNESCO, Oxford.

Ezeaku, I.E., B.N. Mbah, K.P. Baiyeri, \& E.C. Okechukwu. 2015. Integrated crop-livestock farming system for sustainable agricultural production in Nigeria. Afr. J. Agric. Res. 10:4268-4274. https://doi.org/10.5897/AJAR2015.9948 
Fernández-López, J., E. Sendra,; E. Sayas-Barberá, C. Navarro, \& J.A. Pérez-Alvarez. 2008. Physico-chemical and microbiological profiles of "salchich" (Spanish dry-fermented sausage) enriched with orange fiber. Meat Sci. 80: 410-417. https://doi.org/10.1016/j.meatsci.2008.01.010

Grose, C.J. 1999. Land Cappability Handbook: Guidelines for the Classification of Agricultural Land in Tasmania. Departement of Primary Industries, Water and Environment, Tasmania.

Gupta, V., P.K. Rai, \& K.S. Risam. 2012. Integrated crop-livesstock farming systems : a strategy for resource conservation and environmental sustainability. Indian Research Journal of Extension Education. 2. Special Issue : 49-54

Hamuda, H.E.A.F \& I.. Patkŏ. 2010. Relationship between environtmental Impacts and modern Agriculture. Obbuda univ. 1.1:87-98

Hillmire, K. 2011. Integrated crop/livestock agriculture in the united states: a review. J. Sustain. Agric. 35:376-393. https:// doi.org/10.1080/10440046.2011.562042

Hoekstra, A.Y. 2012. The hidden water resource use behind meat and dairy. Animal Frontiers. 2: 3-8. https://doi. org/10.2527/af.2012-0038

Ismael, A.J., Ch.L. Kaunang, K. Maaruf, \& M. Waani. 2018. Daya dukung bahan kering, protein kasar dan total digestible nutrien limbah tanaman pangan sebagai pakan ruminansia di Kecamatan Talawaan Kabupaten Minahasa Utara. Zootek Journal. 38:17-26.

Johannsen, S.S. \& P. Armitage. 2010. Agricultural practice and the effects of agricultural land-use on water quality. Freshwater forum. 28:45-59

Kasapidou, E., E. Sossidou, and P. Mitlianga. 2015. Fruit and vegetable co-products as functional feed inredients in farm animal nutrition for improved product quality. Agriculture. 5: 1020-1034. https://doi.org/10.3390/ agriculture 5041020

Kemenkopmk. 2014. UU nomor 41 tahun 2014, tentang perubahan atas undang-undang nomor 18 tahun 2009 tentang peternakan dan kesehatan hewan. https://www.kemenkopmk.go.id/content/uu-nomor-41-tahun-2014. [5 October 2017]

Lange, A., R. Siebert, \& T. Barkman. 2015. Sustainability and land management: an analysis of stakeholder perceptions in rural Northern Germany. Sustainability. 7:683-704. https://doi.org/10.3390/su7010683

Mijinyawa, Y. \& S.S. Dlamini. 2008. Impact assessment of water scarcity at Somntongo in the lowveld region of Swaziland. Scientific Research and Essay. 3:61-65

Pretty, J. \& Z.P. Bharucha. 2014. Sustainable intensification in agricultural systems. Annals of Botany. 114:1571-1596. https://doi.org/10.1093/aob/mcu205

Rahman, M.M., T. Nakaagawa, R.B. Abdullah, W.K.W. Embong, \& R. Akashi. 2014. Feed intake and growth performance of goats supplemented with soy waste. Pesquisa Agropecuaria Brasileira. 49:554-558

Rahman, S. 2015. Green revolution in India : environmental degradation and impact on livestock. Asian Journal of
Water, Environment and Pollution. 12:75-80. https://doi. org/10.1590/S0100-204X2014000700008

Salemdeeb, R., E.K.H.J Ermgassen, M.H. Kim, A. Balmford, \& A. Al-Abbaa. 2017. Environtmental and health impacts of using food waste as animal feed : a comparative analysis of food waste management options. J. Clean. Prod. 2:871-880. https://doi.org/10.1016/j.jclepro.2016.05.049

Santosa, B., Surjono, A. Rachmansyah, \& Soemarno. 2014. Strategy development of western east java industrial area. American Journal of Sociological Research. 4:42-52.

Schieber, A., F.C. Stintzing, \& R. Carle. 2001. By-products of plant food processing as a source of functional compounds-Recent developments. Trends Food Sci. Technol. 12:401-413. https://doi.org/10.1016/S0924-2244(02)00012-2

Schlink, A.C, M.L Nguyen, \& G.J. Viljoen. 2011. Water requirements for livestock production: a global perspective. Rev. Sci. Tech. 29: 603-619.

Scholtz, M.M., J.B.J. van Ryssen, H.H. Meissner, \& M.C. Laker. 2013. A south african perspective on livestock production in relation to greenhouse gases and water usage. S. Afr. J. Anim. Sci. 43:247-254. https://doi.org/10.4314/sajas.v43i3.2

Schroll, H. J. Andersen, \& B. Kjærgård. 2012. Carrying capacity: an approach to local spatial planning in Indonesia. The Journal of Transdiciplinary Environmental Studies. 11:27-39.

Soedjana, T.D. 2007. Masalah dan kebijakan peningkatan produksi peternakan untuk pemecahan gizi masyarakat. http://www.lit-bang.deptan.go.id/. [5 October 2017].

Sonneveld, B.G.J.S, M.A. Keyzer \& D. Ndiaye. 2016. Quantifying the impact of land degradation on crop production : the case of Senegal. Solid Earth. 7:93-103. https:// doi.org/10.5194/se-7-93-2016

Sorathiya, L.M., A.B. Fulsoundar, K.K. Tyagi, M.D. Patel, \& R.R. Singh. 2014. Eco-friendly and modern methods of livestock waste recycling for enhancing farm profitability. International Journal of Recycling of Organic Waste In Agriculture. 3:50. https://doi.org/10.1007/ s40093-014-0050-6

Surendra, K.C., R. Olivier, J.K. Tomberlin, R. Jha, \& S.K. Khanal. 2016. Bioconversion of organic wastes into biodesel and animal feed via insect farming. Renewable energy. 98: 197-202. https://doi.org/10.1016/j.renene.2016.03.022

Tesfa, A. \& A. Mekuriaw. 2014. The effect of land degradation on farm size dynamics and crop-livestock farming system in ethiopia: A Review. Journal of Soil Science. 4:1-5. https:// doi.org/10.4236/ojss.2014.41001

Thornton, P.K. 2010. Livestock production: recent trends, future prospect. Philosophical Transactions of the Royal Society B: Biological Sciences. 365:2853-2867. https:/doi. org/10.1098/rstb.2010.0134

Yosef, B.A. \& D.K. Asmamaw. 2015. Rainwater harvesting : an option for dry land agriculture in arid and semiarid Ethiopia. International Journal of Water Resources and Environmental Engineering. 7:17-28. https://doi. org/10.5897/IJWREE2014.0539 